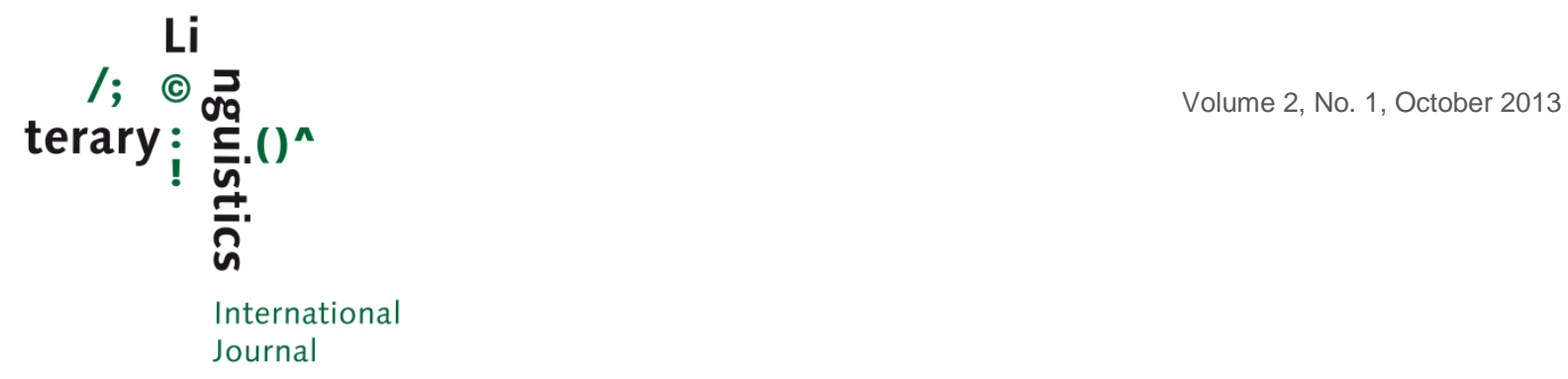

\title{
There is no psychological limit on the duration of metrical lines in performance: Against Turner and Pöppel
}

\author{
Keywords: \\ Metre, \\ performance, \\ time, line, \\ working \\ memory
}

\section{Nigel Fabb}

Abstract: Frederick Turner and Ernst Pöppel (1983) proposed that lines of metrical poetry tend to measure three seconds or less when performed aloud, and that the metrical line is fitted to a three second 'auditory present' in the brain. In this paper I show that there are faults both in their original argument, and in the claims which underlie it. I present new data, based on the measurement of line durations in publicly available recorded performances of 54 metrical poems; in this corpus, lines of performed metrical verse are often longer than three seconds: $59 \%$ of the 1155 lines are longer than 3 seconds, $40 \%$ longer than 3.5 seconds and $26 \%$ longer than 4 seconds. On the basis of weaknesses in the original paper, and the new data presented here, I propose, against Turner and Pöppel, that there is no evidence that lines of verse are constrained by a time-limited psychological capacity.

\section{Introduction}

The 'metrical line' is a section of text whose length is fixed by rule, often with some regulated variation. For example, a metrical line in the meter iambic pentameter' is normally ten syllables long, but there are also eleven syllable variants. Length is fixed by counting syllables, or morae (sub-syllabic units). Many meters also control other aspects of the line, notably its rhythm, and this is also true of iambic pentameter which produces lines which tend to be stressed on even-numbered syllables. Metrical verse is quite widespread: it is common in the literatures of Europe and Asia, and in some African literatures, and there are a few reports of metrical verse elsewhere. ${ }^{1}$

The general question this paper addresses is whether there is a time-based psychological factor influencing the upper length of metrical lines. This claim is made in a frequently-cited 1983 article by the literary critic Frederick Turner and the neuroscientist Ernst Pöppel (henceforth TP, with page numbers drawn from

\footnotetext{
${ }^{1}$ TP incorrectly claim that metrical verse is a universal, found widely in the literatures of the world. In fact there are almost no reports of metrical verse (apart from imports) from non-Islamic Africa, the Americas, and Australia. This partly undermines their argument for the privileged status of metrical verse.
} 
the Turner 1992 reprinting). ${ }^{2}$ They claim (1) that spoken metrical lines last around three seconds, (2) that we have a psychological capacity to hold about three seconds of heard speech at one time, and thus (3) that there is a match between metrical verse and human psychology:

Of more specific significance for our subject is the very exact correlation between the three-second LINE and the three-second 'auditory present'. This extraordinary correlation is the major finding of this essay: it points to an explanation of the prevalence of the three-second LINE. (Turner 1992: 91)

In the present paper, I argue that TP are wrong, and that there is no evidence for a psychologically derived time-based limit on metrical lines. Time is a characteristic of the performance of verse, not a textual characteristic. This has some relevance for the debate between empiricist/embodiment/contextual approaches to poetry (associated with many types of cognitive poetics) and rationalist/generative/formalist approaches to poetry (associated with generative metrics, as e.g., in Fabb and Halle 2008). If time were relevant, it would be an argument in favour of empiricist/embodiment/contextual approaches, which would see the characteristics of the verse as arising from its manifestation in the world as performance in the temporal world. Since time is not relevant, this suggests that any generalizations which may be found about lines might better be found at the level of decontextualized underlying atemporal form.

TP continues to be cited, for example in a discussion of cognition and time by Evans (2007: 735), and in the evolutionary account of poetry by Boyd (2012: 16), and in the entry on 'sound' in the Princeton Encyclopedia of Poetics (Greene 2012). However, Holder (1995: 68-70) finds faults in its argumentation, and Kien and Kemp (1994) provide new data which undermines some of its claims. The present paper is however the first to provide extensive data from a large corpus with the specific goal of disproving the claims by TP. In a hostile review of TP, Nelson (2000) usefully locates the paper in terms of Frederick Turner's association with a group of American poets and critics who describe themselves as 'new formalist'. According to Nelson, this group is opposed to free verse, and seeks to reinstate metrical verse in contemporary American poetry. The vehemence of this viewpoint, and its role in driving the TP hypothesis can be seen in the final sentences of TP, which attack free verse as a practice: 'Thus free verse, like existentialist philosophy, is nicely adapted to the needs of the bureaucratic and even the totalitarian state, because of its confinement of human concern within narrow specialized limits where it will not be politically threatening' (Turner 1992: 104). This desire to draw a sharp distinction between metrical and free verse is part of the motivation for wanting to make the claim that metrical lines are temporally fitted to human psychology but that free verse lines are not. In Fabb (2010), I discuss and criticize this

\footnotetext{
2 Turner and Pöppel's argument is published as Turner and Pöppel $(1983,1988)$ and Turner (1992); the three papers are very close textually, and I quote from the last published, while referring to the authors and the general argument they propose as TP.
} 
common opposition between traditional literature and modernist literature in terms of an opposition between fit-for-cognition and unfit-for-cognition. The present paper shows that there is no psychologically-set durational constraint which distinguishes metrical from non-metrical verse, and thus undermines at least part of TP's argument against the supposed poor fit of free verse to human psychology.

\section{Measuring the durations of spoken lines}

TP present very little evidence for their claim that spoken lines of metrical verse are limited in duration. For example, for English metrical verse, they present just the results below (Turner 1992: 76).

LINE durations

Pentameter

Seven-syllable trochaic line

Stanzas using different line lengths

Ballad meter (octosyllabic)
3.30 secs

2.50 secs

3.00 secs, 3.10 secs

2.40 secs

Though it is not made explicit by TP, I assume that these are average line durations based on a corpus, either an average duration for all the lines in this meter, or an average of each poem's average line durations. Turner (1992) presents similar results for other poetic traditions which he and Pöppel have 'recorded and measured'. For some other traditions, he also presents some predicted results where there are no actual measurements, by calculating the number of syllables in the line and combining this with an estimated rate of syllables per second. ${ }^{3}$

The evidence presented by TP is unsatisfactory for several reasons. It is unverifiable: there is no record of what texts were performed or who performed them (it may have been Turner and Pöppel themselves, but this is not explicit). Furthermore, all we are given is (what appear to be) the average durations of lines for a corpus of poems in a specific meter; other kinds of relevant information are not given, such as how many lines are above a certain duration. In order to make up for the weaknesses in the evidence given in TP, I have conducted in collaboration with Stefano Versace a new survey. This is a survey of 54 metrical English poems (1155 lines in total), which measures the durations of spoken lines, 35 of which are in iambic pentameter and the others in other

\footnotetext{
${ }^{3}$ There are various problems with this. Languages and dialects vary in average syllables per second, and variation can also depend on age, speaker, and gender. Furthermore, genre of text or performance also has an influence on tempo. We will see later that poems may be spoken at a slower tempo (fewer syllables per second) than other kinds of speech. None of this seems to have been taken into account by TP, rendering their predicted syllable counts (where they undertook no actual measurements) useless. See Trouvain (2003) for discussion of factors influencing speech tempo.
} 
meters. The results are summarized in Table 1, which is explained in detail in the pages following the Table.

\begin{tabular}{|c|c|c|c|c|c|c|c|c|c|c|}
\hline A & B & C & D & $\mathrm{E}$ & $\mathrm{F}$ & G & $\mathrm{H}$ & 1 & J & K \\
\hline short title & meter etc & 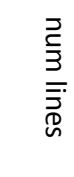 & 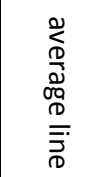 & 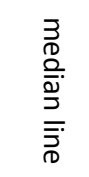 & 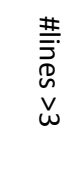 & $\begin{array}{l}\stackrel{d}{ } \\
\overline{\bar{B}} \\
0 \\
\stackrel{D}{\omega} \\
\omega\end{array}$ & 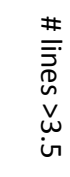 & 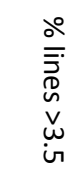 & $\begin{array}{l}\text { \#. } \\
\overline{\bar{D}} \\
\stackrel{D}{0} \\
\vee\end{array}$ & $\begin{array}{l}\stackrel{\circ}{\circ} \\
\overline{\bar{D}} \\
\stackrel{D}{x}\end{array}$ \\
\hline $\begin{array}{l}\text { Frost } \\
\text { Nothing gold }\end{array}$ & $\begin{array}{l}\text { iambic } \\
\text { trimester }\end{array}$ & 8 & 1.97 & 1.97 & 0 & 0 & 0 & 0 & 0 & 0 \\
\hline $\begin{array}{l}\text { Parker } \\
\text { Resumé }\end{array}$ & $\begin{array}{l}\text { loose } \\
\text { trochaic } \\
\text { dimeter }\end{array}$ & 8 & 1.28 & 1.30 & 0 & 0 & 0 & 0 & 0 & 0 \\
\hline $\begin{array}{l}\text { Frost } \\
\text { Stopping }\end{array}$ & $\begin{array}{l}\text { iambic } \\
\text { tetram. }\end{array}$ & 16 & 2.27 & 2.25 & 0 & 0 & 0 & 0 & 0 & 0 \\
\hline $\begin{array}{l}\text { Parker } \\
\text { Afternoon }\end{array}$ & $\begin{array}{l}\text { iambic } \\
\text { tri- and } \\
\text { tetram. }\end{array}$ & 16 & 1.93 & 1.83 & 0 & 0 & 0 & 0 & 0 & 0 \\
\hline $\begin{array}{l}\text { Auden If I } \\
\text { could }\end{array}$ & $\begin{array}{l}\text { iambic } \\
\text { pentam. }\end{array}$ & 19 & 2.60 & 2.60 & 0 & 0 & 0 & 0 & 0 & 0 \\
\hline $\begin{array}{l}\text { Ransom } \\
\text { Bells }\end{array}$ & $\begin{array}{l}\text { loose } \\
\text { iambic } \\
\text { tetram. }\end{array}$ & 20 & 2.65 & 2.69 & 6 & 30 & 0 & 0 & 0 & 0 \\
\hline Plath Ariel & $\begin{array}{l}\text { not } \\
\text { metrical }\end{array}$ & 31 & 1.50 & 1.50 & 0 & 0 & 0 & 0 & 0 & 0 \\
\hline $\begin{array}{l}\text { Graves To } \\
\text { Juan }\end{array}$ & $\begin{array}{l}\text { loose } \\
\text { heterom } \\
\text { etric }\end{array}$ & 42 & 2.29 & 2.30 & 6 & 14 & 0 & 0 & 0 & 0 \\
\hline $\begin{array}{l}\text { Roethke I } \\
\text { knew }\end{array}$ & $\begin{array}{l}\text { iambic } \\
\text { pentam. }\end{array}$ & 28 & 2.94 & 2.95 & 11 & 39 & 1 & 4 & 0 & 0 \\
\hline $\begin{array}{l}\text { Frost Gift } \\
\text { Outright }\end{array}$ & $\begin{array}{l}\text { iambic } \\
\text { pentam. }\end{array}$ & 16 & 2.93 & 2.95 & 7 & 44 & 1 & 6 & 0 & 0 \\
\hline $\begin{array}{l}\text { Ransom } \\
\text { Captain }\end{array}$ & $\begin{array}{l}\text { iambic } \\
\text { pentam. } \\
\text { (variant) }\end{array}$ & 45 & 2.60 & 2.60 & 10 & 22 & 3 & 7 & 0 & 0 \\
\hline $\begin{array}{l}\text { Gonet/Sh } \\
\text { son } 30\end{array}$ & $\begin{array}{l}\text { iambic } \\
\text { pentam. }\end{array}$ & 14 & 2.89 & 2.81 & 4 & 29 & 1 & 7 & 0 & 0 \\
\hline $\begin{array}{l}\text { Millay I shall } \\
\text { forget }\end{array}$ & $\begin{array}{l}\text { iambic } \\
\text { pentam. }\end{array}$ & 14 & 3.02 & 2.97 & 6 & 43 & 1 & 7 & 0 & 0 \\
\hline $\begin{array}{l}\text { Frost } \\
\text { Birches }\end{array}$ & $\begin{array}{l}\text { iambic } \\
\text { pentam. }\end{array}$ & 42 & 2.69 & 2.70 & 10 & 24 & 3 & 7 & 0 & 0 \\
\hline $\begin{array}{l}\text { Frost Road } \\
\text { not taken }\end{array}$ & $\begin{array}{l}\text { loose } \\
\text { iambic }\end{array}$ & 20 & 2.63 & 2.51 & 3 & 15 & 2 & 10 & 0 & 0 \\
\hline
\end{tabular}




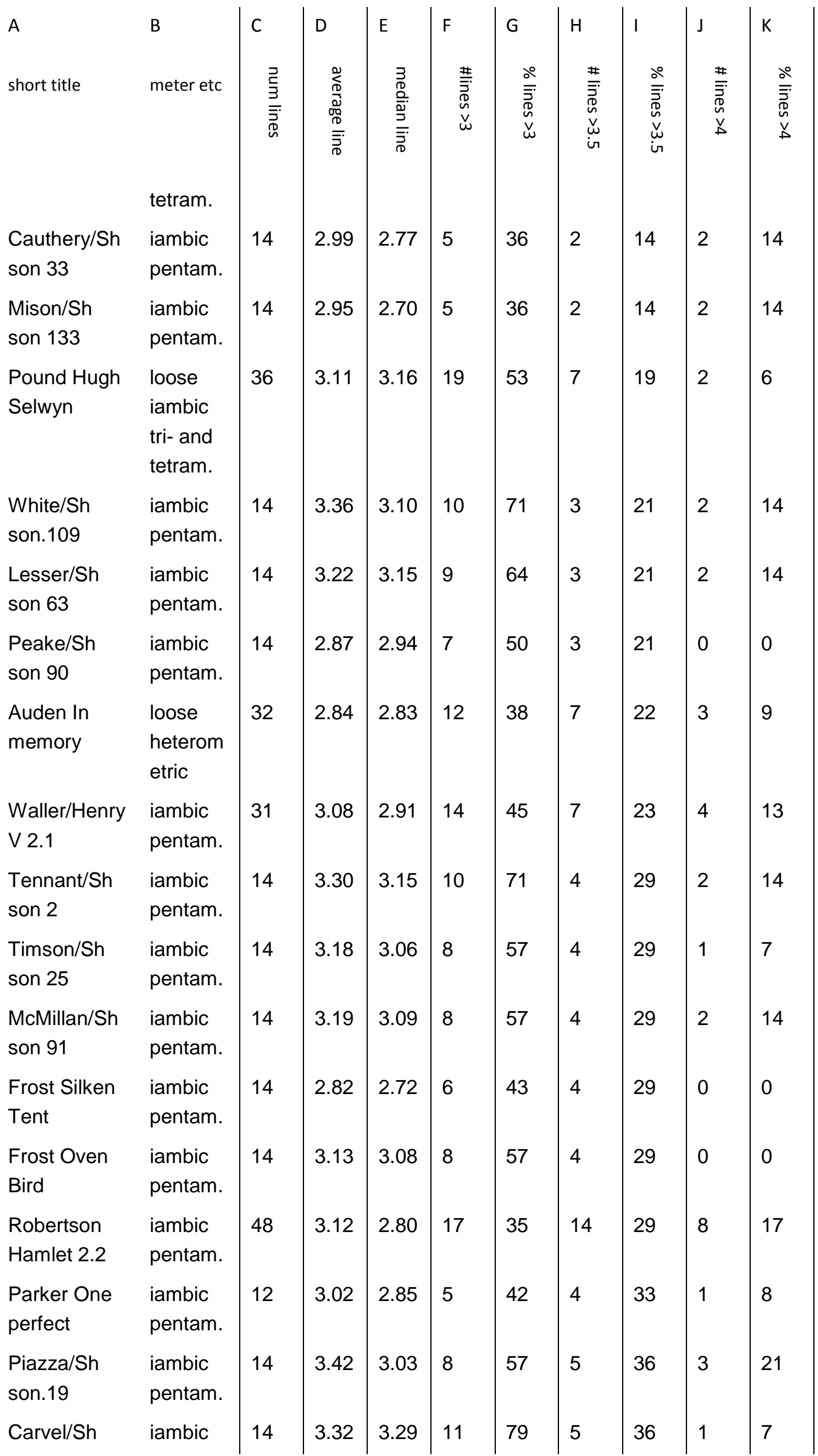




\begin{tabular}{|c|c|c|c|c|c|c|c|c|c|c|}
\hline A & B & C & D & $\mathrm{E}$ & $\mathrm{F}$ & G & $\mathrm{H}$ & 1 & J & $\mathrm{K}$ \\
\hline short title & meter etc & 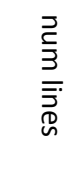 & 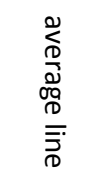 & 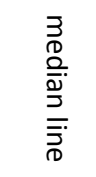 & 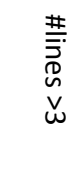 & $\begin{array}{l}\stackrel{\circ}{.} \\
\stackrel{\bar{D}}{0} \\
\stackrel{0}{\omega} \\
\stackrel{\omega}{v}\end{array}$ & 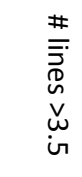 & $\begin{array}{l}\stackrel{\circ}{0} \\
\overline{\bar{\sigma}} \\
\stackrel{D}{D} \\
\stackrel{v}{w} \\
i\end{array}$ & 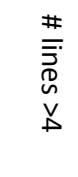 & 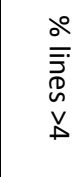 \\
\hline son. 6 & pentam. & & & & & & & & & \\
\hline $\begin{array}{l}\text { Soames/Sh } \\
\text { son } 50\end{array}$ & $\begin{array}{l}\text { iambic } \\
\text { pentam. }\end{array}$ & 14 & 3.33 & 3.29 & 8 & 57 & 5 & 36 & 2 & 14 \\
\hline $\begin{array}{l}\text { Gielgud } \\
\text { Richard II } \\
3.3\end{array}$ & $\begin{array}{l}\text { iambic } \\
\text { pentam. }\end{array}$ & 48 & 4.32 & 3.49 & 34 & 71 & 23 & 48 & 22 & 46 \\
\hline $\begin{array}{l}\text { Keeble/Sh } \\
\text { son.127 }\end{array}$ & $\begin{array}{l}\text { iambic } \\
\text { pentam. }\end{array}$ & 14 & 3.66 & 3.55 & 13 & 93 & 7 & 50 & 3 & 21 \\
\hline $\begin{array}{l}\text { Robertson/H } \\
\text { amlet } 3.2\end{array}$ & $\begin{array}{l}\text { iambic } \\
\text { pentam. }\end{array}$ & 43 & 3.64 & 3.52 & 35 & 81 & 22 & 51 & 15 & 35 \\
\hline $\begin{array}{l}\text { Ross/Sh son } \\
20\end{array}$ & $\begin{array}{l}\text { iambic } \\
\text { pentam. }\end{array}$ & 14 & 3.72 & 3.65 & 11 & 79 & 8 & 57 & 6 & 43 \\
\hline $\begin{array}{l}\text { Gielgud/Ham } \\
\text { let } 4.4\end{array}$ & $\begin{array}{l}\text { iambic } \\
\text { pentam. }\end{array}$ & 35 & 4.10 & 3.80 & 28 & 80 & 21 & 60 & 17 & 49 \\
\hline $\begin{array}{l}\text { Millay } \\
\text { Recuerdo }\end{array}$ & $\begin{array}{l}\text { loose } \\
\text { iambic } \\
\text { tetram. }\end{array}$ & 18 & 3.80 & 3.80 & 16 & 89 & 11 & 61 & 7 & 39 \\
\hline $\begin{array}{l}\text { Thomas/Dov } \\
\text { er Beach }\end{array}$ & $\begin{array}{l}\text { iambic } \\
\text { heterom } \\
\text { etric }\end{array}$ & 37 & 3.73 & 3.67 & 30 & 81 & 23 & 62 & 13 & 35 \\
\hline $\begin{array}{l}\text { Togan Ex- } \\
\text { Judge }\end{array}$ & $\begin{array}{l}\text { loose } \\
\text { iambic } \\
\text { pentam. }\end{array}$ & 32 & 4.06 & 3.99 & 26 & 81 & 20 & 63 & 16 & 50 \\
\hline $\begin{array}{l}\text { cummings } \\
\text { next to }\end{array}$ & $\begin{array}{l}\text { iambic } \\
\text { pentam. }\end{array}$ & 14 & 3.69 & 3.62 & 12 & 86 & 9 & 64 & 3 & 21 \\
\hline $\begin{array}{l}\text { cummings } \\
\text { anyone }\end{array}$ & $\begin{array}{l}\text { loose } \\
\text { iambic } \\
\text { tetram. }\end{array}$ & 36 & 4.80 & 4.80 & 31 & 86 & 26 & 72 & 23 & 64 \\
\hline $\begin{array}{l}\text { Irving/Richar } \\
\text { d III } 1.1\end{array}$ & $\begin{array}{l}\text { iambic } \\
\text { pentam. }\end{array}$ & 11 & 4.03 & 3.84 & 11 & 100 & 8 & 73 & 4 & 36 \\
\hline $\begin{array}{l}\text { Spender } \\
\text { Rough }\end{array}$ & $\begin{array}{l}\text { loose } \\
\text { iambic } \\
\text { heterom } \\
\text { etric }\end{array}$ & 12 & 3.72 & 3.68 & 11 & 92 & 9 & 75 & 3 & 25 \\
\hline $\begin{array}{l}\text { Millay Love } \\
\text { is not }\end{array}$ & $\begin{array}{l}\text { iambic } \\
\text { pentam. }\end{array}$ & 15 & 3.99 & 4.17 & 14 & 93 & 12 & 80 & 8 & 53 \\
\hline Bourchier/M & iambic & 38 & 5.28 & 4.80 & 36 & 95 & 31 & 82 & 28 & 74 \\
\hline
\end{tabular}




\begin{tabular}{|c|c|c|c|c|c|c|c|c|c|c|}
\hline A & B & C & D & $\mathrm{E}$ & $\mathrm{F}$ & G & $\mathrm{H}$ & I & J & K \\
\hline short title & meter etc & 永 & 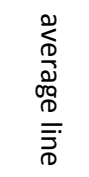 & 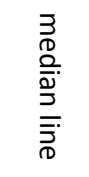 & 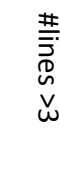 & 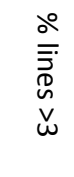 & 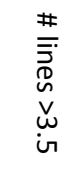 & 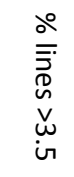 & 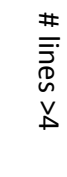 & 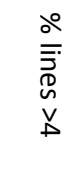 \\
\hline acbeth 2.1 & pentam. & & & & & & & & & \\
\hline $\begin{array}{l}\text { Tennyson } \\
\text { Bugle song }\end{array}$ & $\begin{array}{l}\text { iambic } \\
\text { tetram. } \\
\text { (plus) }\end{array}$ & 6 & 4.74 & 4.39 & 6 & 100 & 5 & 83 & 3 & 50 \\
\hline $\begin{array}{l}\text { Tree/Julius } \\
\text { Caesar. } 3.1\end{array}$ & $\begin{array}{l}\text { iambic } \\
\text { pentam. }\end{array}$ & 22 & 4.31 & 4.11 & 22 & 100 & 19 & 86 & 12 & 55 \\
\hline $\begin{array}{l}\text { Yeats Coole } \\
\text { Park }\end{array}$ & $\begin{array}{l}\text { iambic } \\
\text { pentam. }\end{array}$ & 16 & 4.10 & 3.89 & 15 & 94 & 14 & 88 & 7 & 44 \\
\hline $\begin{array}{l}\text { Thomas/Don } \\
\text { ne hymn }\end{array}$ & $\begin{array}{l}\text { iambic } \\
\text { pentam. }\end{array}$ & 30 & 4.59 & 4.43 & 30 & 100 & 27 & 90 & 21 & 70 \\
\hline $\begin{array}{l}\text { Bogan } \\
\text { Dream }\end{array}$ & $\begin{array}{l}\text { loose } \\
\text { iambic } \\
\text { pentam. }\end{array}$ & 16 & 5.32 & 5.23 & 16 & 100 & 16 & 100 & 16 & 100 \\
\hline $\begin{array}{l}\text { Yeats Old } \\
\text { Mother }\end{array}$ & $\begin{array}{l}\text { loose } \\
\text { iambic } \\
\text { tetram. }\end{array}$ & 10 & 4.20 & 4.12 & 10 & 100 & 10 & 100 & 6 & 60 \\
\hline $\begin{array}{l}\text { Yeats Lake } \\
\text { Isle }\end{array}$ & $\begin{array}{l}\text { loose } \\
\text { iambic } \\
\text { hexamet } \\
\text { er }\end{array}$ & 12 & 5.16 & 5.23 & 12 & 100 & 12 & 100 & 10 & 83 \\
\hline $\begin{array}{l}\text { Bogan Last } \\
\text { Act }\end{array}$ & $\begin{array}{l}\text { iambic } \\
\text { pentam. }\end{array}$ & 27 & 4.77 & 4.74 & 27 & 100 & 27 & 100 & 23 & 85 \\
\hline
\end{tabular}

Table 1: Line durations, metrical texts.

The poems are all in English and are all metrical (in strict or loose meters ${ }^{4}$ ); my only guiding principle for selecting performances was that all are available as publicly accessible recordings so that the findings could be independently checked if necessary. The corpus of performances consists mostly of poems read by their authors, some old recordings of dramatic verse from Shakespeare, and Shakespeare sonnets each read by a different actor. My extensive use of Shakespeare recordings means that the majority of the poems are in iambic pentameter. One disadvantage with using already-recorded materials is that it is possible that the mechanical recording process has slightly changed the timings, for example, perhaps making the recordings slightly faster or slower than the actual spoken performances. We understand very little about any

\footnotetext{
${ }^{4}$ The term 'loose meter' refers here to meters in which the number of stressed syllables is fairly stable, but in which the number of unstressed syllables between stresses can vary usually from zero to two unstressed syllables. This means that there are often different numbers of syllables in subsequent lines. See Fabb and Halle (2008) for further discussion.
} 
potential contributing factors to the duration of performed lines, which might skew the results for any particular corpus in a specific way. It may be that performed lines vary in duration in correlation with characteristics of the speaker, such as dialect, gender or age, correlation with whether the poem is improvised, read aloud, or remembered, or correlation with characteristics of the recording context such as live recording before an audience or recording in a studio. From the small sample analysed here, no clear correlations can be seen.

Analysis of data was undertaken using Praat, the free speech-analysis software written by Paul Boersma and David Weenink; most of the measurements were carried out for this project by Stefano Versace. Measurements were made by importing the sound files into Praat, producing textgrids, demarcating line boundaries, and adding text and pause markers into the textgrid; then exporting sections and section lengths into Microsoft Excel for further analysis. It is strictly line durations which are measured (any line-internal pauses add to the measured duration). Whether a line ends with a pause or runs without pause into the next line is irrelevant for these measurements, as, following one of the fundamental claims of TP, it is strictly lines whose durations are to be measured. Pauses are non-linguistic gaps between linguistic material and can either be silent or filled with an audible intake of breath. The location of the line boundary was judged by ear and by looking at the soundwave, placing the boundary at the final part of the final sound of the word.

To illustrate the approach, Figure 1 below shows the results for Shakespeare's sonnet 127, performed by Jonathan Keeble, annotated so that [] marks a pause and / a line boundary, and the numbers are durations in seconds per line or per pause. Thus for example line 1 contains two internal pauses, after the fourth and fifth syllables. From the beginning of the word 'In' to the end of the word 'fair' the line lasts 4.65 seconds. It is followed by a pause of 0.62 seconds before the next line starts.

1 In the old age [] black [] was not counted fair, / []

2 Or if it were, it bore not beauty's name; / []

3 But now [] is black beauty's successive heir, / []

4 And beauty slander'd [] with a bastard shame: / [] 
6 Fairing the foul with art's false borrow'd face, /

[]

7 Sweet beauty hath no name, [] no holy bower, /

[]

8 But is profaned, [] if not lives in disgrace. /

[]

9 Therefore [] my mistress's eyes are raven black, /

[]

10 Her eyes so suited, and they mourners seem /

11 At such who, not born fair, no beauty lack, /

[]

12 Slandering creation with a false esteem: /

13 Yet so they mourn, [] becoming of their woe, /

14 That every tongue [] says beauty should look so. /

Figure 1. Shakespeare sonnet 127 performed by Jonathan Keeble: lines and pauses.

On the basis of analysing 54 poems (1155 lines) in this manner, Table 1 (above) was constructed. An explanation of the columns follows. Column A gives the short title for each text (full details given in appendix 1). Column B names the meter. Trochaic dimeter normatively has 4 syllables, iambic trimeter 6 syllables, iambic tetrameter 8 syllables, iambic pentameter 10 syllables. Loose versions of these meters can have shorter or longer lines, within limits. Heterometric meters vary more greatly in length. ${ }^{5}$ Column $\mathbf{C}$ gives the number of lines in each poem. Column $\mathbf{D}$ presents the average of the durations of the lines in each poem as spoken, measured in seconds. For Keeble's performance of sonnet 127 , the average line duration is 3.66 seconds. Average line duration is presented here because this is the measure used by TP, though I argue later that it is uninformative. Column E presents the median of the durations of the lines in each poem as spoken, measured in seconds. For Keeble's performance of sonnet 127, the median line duration is 3.55 seconds. Median line duration is presented here because this is the measure used by Kien and Kemp (1994); as

\footnotetext{
${ }^{5}$ For illustration of English meters, and a theoretical account of how syllables are counted, see Fabb and Halle (2008).
} 
with average line duration, I argue later that it is uninformative.$^{6}$ Column $\mathbf{F}$ shows how many lines in each poem are longer than 3 seconds, and column $\mathbf{G}$ gives this as a percentage of lines in each poem. For Keeble's performance of the 14-line sonnet 127, there are 13 lines (93\%) longer than 3 seconds. Column $\mathbf{H}$ shows how many lines in each poem are longer than 3.5 seconds, and column I gives this as a percentage of lines in each poem. For Keeble's performance of sonnet 127, there are 7 lines (50\%) longer than 3.5 seconds. I have ordered the Table by ranking the percentage figures in column I; this is probably the most important finding because if around 3 seconds is an upper predicted limit, then we would expect very few lines to be longer than 3.5 seconds. It can be seen from the Table that this is not the case: many poems in the corpus have a high percentage of lines longer than 3.5 seconds. Column $\mathbf{J}$ shows how many lines in each poem are longer than 4 seconds, and Column $\mathbf{K}$ gives this as a percentage of lines in each poem. For Keeble's performance of sonnet 127, there are 3 lines (21\%) longer than 4 seconds.

A summary of the results in Table 1 is given in Tables 2 and 3.

\begin{tabular}{|l|l|l|l|}
\hline & $\begin{array}{l}\text { longer than 3 } \\
\text { seconds }\end{array}$ & $\begin{array}{l}\text { longer than 3.5 } \\
\text { seconds }\end{array}$ & $\begin{array}{l}\text { longer than 4 } \\
\text { seconds }\end{array}$ \\
\hline $\begin{array}{l}\text { average line duration } \\
\text { per poem }\end{array}$ & $61 \%$ & $41 \%$ & $26 \%$ \\
\hline $\begin{array}{l}\text { median line duration } \\
\text { per poem }\end{array}$ & $59 \%$ & $39 \%$ & $19 \%$ \\
\hline
\end{tabular}

Table 2. Percentages of poems in the corpus of 54 poems which have average and median line durations above certain levels.

\begin{tabular}{|l|l|l|l|}
\hline & $\begin{array}{l}\text { longer than 3 } \\
\text { seconds }\end{array}$ & $\begin{array}{l}\text { longer than 3.5 } \\
\text { seconds }\end{array}$ & $\begin{array}{l}\text { longer than 4 } \\
\text { seconds }\end{array}$ \\
\hline actual line durations & $59 \%$ & $40 \%$ & $26 \%$ \\
\hline
\end{tabular}

Table 3. Percentages of lines in the corpus of 1155 lines which are above a certain duration.

lambic pentameter lines are the most common in the corpus (733 lines in 35 poems), and Tables 4 and 5 show the results specifically for iambic pentameter lines.

\footnotetext{
${ }^{6}$ The average line duration is calculated by adding the lengths of all the lines, and dividing by the number of lines. Thus for Keeble's performance, adding $4.65+2.84+3.45+3.49+3.05+4.74+3.6$ $+3.87+4.51+3.77+3.67+3.03+3.08+3.48$ then dividing the total of 51.23 by $14=3.66$. The median line duration is derived by ordering the lines by length - here 2.84, 3.03, 3.05, 3.08, 3.45, $3.48,3.49,3.6,3.67,3.77,3.87,4.51,4.65,4.74$ - and choosing the middle one, or the average of the two middle ones where there are an even number as here. The two lines in the middle of this fourteen-line sequence are 3.49 and 3.6 seconds long and so the median is 3.55 seconds.
} 


\begin{tabular}{|l|l|l|l|}
\hline & $\begin{array}{l}\text { longer than 3 } \\
\text { seconds }\end{array}$ & $\begin{array}{l}\text { longer than 3.5 } \\
\text { seconds }\end{array}$ & $\begin{array}{l}\text { longer than 4 } \\
\text { seconds }\end{array}$ \\
\hline $\begin{array}{l}\text { average line duration } \\
\text { per poem }\end{array}$ & $74 \%$ & $37 \%$ & $23 \%$ \\
\hline $\begin{array}{l}\text { median line duration } \\
\text { per poem }\end{array}$ & $63 \%$ & $34 \%$ & $14 \%$ \\
\hline
\end{tabular}

Table 4. Percentages of iambic pentameter poems (35 poems) in the corpus which have average and median line durations above certain levels.

\begin{tabular}{|l|l|l|l|}
\hline & $\begin{array}{l}\text { longer than 3 } \\
\text { seconds }\end{array}$ & $\begin{array}{l}\text { longer than 3.5 } \\
\text { seconds }\end{array}$ & $\begin{array}{l}\text { longer than 4 } \\
\text { seconds }\end{array}$ \\
\hline actual line durations & $63 \%$ & $42 \%$ & $27 \%$ \\
\hline
\end{tabular}

Table 5. Percentages of iambic pentameter lines (total 733) in the corpus which are above a certain duration.

Note that Turner (1992) reports iambic pentameter lines as having a 3.30 second duration. We do not know how he reached this figure, but the closest direct comparison may be an average of averages: the average of the 35 iambic pentameter poems' average line durations in my corpus, which is 3.47 seconds.

\section{Is there a time-based psychological constraint on spoken lines of metrical verse?}

This analysis of the 54 metrical poems has produced actual line durations for the 1155 lines comprising the poems. In addition to reporting on the actual line durations, I have calculated average and median line durations for each poem. I include these average and median line durations for comparative purposes, because Turner's (1992) figures are probably based on average line durations, and Kien and Kemp (1994) say that their own figures are based on median line durations.

However, the average duration of lines in any poem can have, as a matter of principle, no bearing on whether any individual line will fit or not fit into a timelimited capacity. No-one hears and processes an average duration line, since an average duration line is an abstraction. The only way in which the average line duration might prove relevant was if the psychological capacity was itself subject to some averaging. Such a hypothesis might say that the capacity is fixed at an average of 3 seconds worth of material measured over a certain length of time, say two minutes, but is able to expand and contract over the course of listening to the poem to reach that average. However, neither Pöppel nor anyone else claims that there is such an averaging out of temporal limits in the psychological capacity. For the reasons outlined in this paragraph, I will henceforth ignore the average line durations, and focus just on actual line durations. (For similar reasons I will also put aside median line durations.) It is actual lines which must fit into some time-limited capacity. 
TP propose as a fact about human psychology that we have a mental capacity which handles current sensory inputs, a kind of consciousness or (though they do not use the term) a working memory capacity, which is subject to a timebased upper limit. The matching of lines to this capacity is a prerequisite for the aesthetic value of these lines. (It is in part because they claim that certain kinds of free verse do not fit, that they claim that free verse is aesthetically valueless.) There is some unclarity in TP as to what they think the real upper limit is of this capacity. Thus though they characterise it as three seconds, they also appear to allow longer lines to fit into the capacity, making it unclear what they think the upper limit actually is. In order for their hypothesis to have some content, though, there must be a clear upper limit for which there is independent evidence, and any line longer than this will be unable to fit. Blurring the upper limit, or allowing some undefined leeway, threatens to undermine their proposal from within.

If there is a limited capacity, then we must ask whether, in any specific performance, any lines actually exceed that capacity. Consider again Keeble's performance of sonnet 127, which in Figure 2 is reordered so that its lines are in sequence of increasing duration, with horizontal lines showing the 3, 3.5 and 4 second divisions.

\begin{tabular}{lll}
2 & Or if it were, it bore not beauty's name; / & 2.84 \\
\hline 12 & Slandering creation with a false esteem: / & 3.03 \\
5 & For since each hand hath put on nature's power, / & 3.05 \\
13 & Yet so they mourn, [] becoming of their woe, / & 3.08 \\
3 & But now [] is black beauty's successive heir, / & 3.45 \\
14 & That every tongue [] says beauty should look so. / & 3.48 \\
4 & And beauty slander'd [] with a bastard shame: / & 3.49 \\
\hline 7 & Sweet beauty hath no name, [] no holy bower, / & 3.60 \\
11 & At such who, not born fair, no beauty lack, / & 3.67 \\
10 & Her eyes so suited, and they mourners seem / & 3.77 \\
8 & But is profaned, [] if not lives in disgrace. / & 3.87 \\
\hline 9 & Therefore [] my mistress's eyes are raven black, / & 4.51 \\
\hline 1 & In the old age [] black [] was not counted fair, / & 4.65 \\
6 & Fairing the foul with art's false borrow'd face, / & 4.74 \\
\hline Table 1: Line durations, metrical texts. &
\end{tabular}

If the upper limit on the psychological capacity is 3 seconds, thirteen of the lines cannot fit into the capacity; if the upper limit is 3.5 seconds, seven lines cannot 
fit into the capacity; if the upper limit is 4 seconds, three lines cannot fit into the capacity. (Or some other result, depending on where the limit is set.) What consequence does it have for lines to fit or not to fit into the capacity? If we follow TP, this failure to fit into the temporal window should have a bad consequence: the performed line would fail because we would not be able to process it as a whole. TP devote much of their article to ambitious explanations of why the processing of the line as a whole, within the three-second window of consciousness has aesthetic and other cognitive consequences; thus, for example 'poetry enforces cooperation between left-brain temporal organization and right-brain spatial organization and helps to bring about that integrated stereoscopic view that we call true understanding' (Turner 1992: 99). The consequence is not good for the corpus of recorded poems analyzed here. For example if the limit is really 3 seconds, then Keeble's is a bad performance of the poem: if it had been performed a bit more quickly, it would have worked better aesthetically, delivering the various aesthetic and other effects claimed by TP. In fact, depending on what one thinks the capacity is, it seems that most of the performed poems in the corpus will fail to deliver the profound results for poetry claimed by TP. Table 3 reveals the problem. If the capacity is set at 3 seconds, then $59 \%$ of the performed lines will not fit; if the capacity is set at 3.5 seconds, then $40 \%$ of the performed lines will not fit; if the capacity is set at 4 seconds, then $26 \%$ of the performed lines will not fit.

I have pushed this conclusion to its limits to show that the notion that lines are subject to a time-based psychological limit is faced with a problem: if it is true, then most performers (including authors as performers) are unaware of it and are unable to adapt their performances to it. If there are consequent aesthetic failures, the performers are unaware of them. I believe this shows that we must abandon the notion that spoken lines must be below a certain duration in order to meet some psychologically-determined aesthetic goal.

Before leaving this issue, we need to consider whether there is an escape clause for TP, based on what TP actually mean by the LINE, as this is the unit whose duration is measured. They say that in many metrical traditions, this is the same as the metrical line. However, where metrical lines are quite long, TP suggest that the metrical line is for measurement purposes divided into two or more distinct LINEs. Thus for example, they suggest that Homer's dactylic hexameter, which is 13-17 syllables long, is quite a long line and so may be divided into two distinct LINEs at the obligatory caesura (the caesura in this meter is a rule requiring a word to end just before or after the middle of the line). They do not make this proposal for English meters such as iambic pentameter. But, to cope with the data presented in the present paper, could we say that iambic pentameter is sometimes a 10-syllable LINE and sometimes divided into two shorter LINES, each of which may be under three seconds? In principle, this could be done by fiat, and so we could create LINEs from this poem which are always less than three seconds. But for this to have any consequence, we would need some independent evidence that the line is so divided, and such evidence does not exist. For example, we might look to the lines of a sonnet such as sonnet 127, and ask whether the line is systematically divided (e.g., by a line-internal pause) at a specific point. The answer is that it is not. An 
examination of the placement of pauses in Keeble's performance of sonnet 127 shows that they fall in the following positions:

$$
\begin{array}{ll}
\text { line } & \text { after mid-line syllable number } \\
1 & 4 \\
& 5 \\
2 & \text { no break } \\
3 & 2 \\
4 & 5 \\
5 & \text { no break } \\
6 & \text { no break } \\
7 & 6 \\
8 & 4 \\
9 & 2 \\
10 & \text { no break (and no line-final break) } \\
11 & \text { no break } \\
12 & \text { no break } \\
13 & 4 \\
14 & 4
\end{array}
$$

Figure 3. Location of mid-line pauses in Keeble's performance of sonnet 127.

Four lines have pauses after the fourth syllable, but two have pauses also after the fifth, one after the sixth and two after the second, and six lines have no internal pauses at all. There is thus no general evidence from pausing that the iambic pentameter line is divided into consistent metrical sub-sections.

The argument I have presented so far involves analysing a corpus and showing that we would have to expand the psychological capacity above three seconds for all the performed lines to fit into the capacity. Perhaps this could be done: if we said that 5 seconds was an upper limit, almost all the lines would fit. One of the problems in assessing the claims made by TP is to assess how large they think the cognitive capacity is. In part of their paper they refer to 'three-second LINE' but in another part of their paper they say that the LINE 'nearly always takes from two to four seconds to recite, with a strong peak in distribution between two-and-a-half and three-and-a-half seconds' (Turner 1992: 74). Because of these uncertainties, it is time to look at the other side of this problem, which is to ask what independent evidence there is for a time-limited psychological capacity for heard language. As I will show, the three second limit (or any longer limit) is not well evidenced, and indeed if there is a limit it is likely to be two rather than three seconds. Given the evidence from the corpus, this finally kills off any claimed match between line durations and time-limited psychological capacity. 


\section{Pöppel 2009}

TP's crucial claim about time and cognition is that 'we possess an auditory information "buffer" whose capacity is three seconds' worth of information; at the end of three seconds the "buffer" is full, and it passes on its entire accumulated stock of information to the higher processing centers' (Turner 1992: 88). The metrical line, according to TP, fits into this three second auditory information buffer. To explore this psychological proposal in more detail, I draw on a more recent publication by Pöppel (2009).

Pöppel argues that neuronal oscillations constrain temporal mechanisms which provide 'pre-semantic integration in the temporal range of approximately 2-3 seconds'. This integration may correspond to 'consciousness' (Pöppel 2009: 1890). It is the 'auditory present' described by TP (quoted above). Pöppel allows for some inter-individual variability in how long the temporal range is, but appears to treat three seconds as an upper limit. Thus for example, he reports a nineteenth-century experiment by Vierordt (1868) which shows that listening subjects can reproduce a heard temporal interval accurately when it is about three seconds in duration; below this level they gradually tend to reproduce inaccurately (overestimating the duration), and above this level they rapidly tend to produce inaccurately (underestimating the duration): that is, above three seconds there is 'a sudden increase to much higher variance'. Pöppel thus suggests that three seconds is an upper boundary of the temporal window of consciousness (Pöppel 2009: 1888).

Pöppel says that the 2-3 second temporal window is manifested in verbal behaviour. This is proposed also by TP who say that '[a] human speaker will pause for a few milliseconds every three seconds or so, and in that period will decide on the precise syntax and lexicon of the next three seconds' and that a listener also stops listening briefly every three seconds (Turner 1992: 87). This is an unusual claim, which I have not been able to find outside Pöppel's work. Pöppel (2009) repeats a similar contention and cites supporting evidence from four published sources: 'Experiments on the temporal structure of spontaneous speech on adults (Vollrath et al. 1992) and on children (Kowal et al. 1975) also show that spoken language is embedded in temporal windows of up to $3 \mathrm{~s}$ duration giving speech its rhythmic structure (Martin 1972; Kien \& Kemp 1994)' (Pöppel 2009: 1892). However, when we examine these sources, we see that they do not all support Pöppel's proposal. Vollrath et.al. (1992) is the most supportive: they recorded 26,387 'singular utterances' (each corresponding to one intonation phrase) of German speakers and found that the median duration was 2.6 seconds, which is in accordance with a temporal window of 3 seconds. (However, they also recorded 43,483 more complex utterances beginning and ending with a pause, and found that they had a median duration of 4.5 seconds, which is longer than the window.) Two of the articles cited as evidence by Pöppel appear to be irrelevant. Thus, Kowal et.al. (1992) does not discuss the duration of speech between pauses (this article is about the duration of pauses themselves), and Martin (1972) also does not discuss timed sequences but rhythmic structure in speech in general. The fourth article provides counterevidence instead of supporting evidence for Pöppel. In this article, Kien 
and Kemp (1994) conduct an experiment showing that there appear to be temporally defined sequences in lines, ${ }^{7}$ but that this is not found in reading prose or in ordinary speech ('no evidence for temporal segmentation in speaking', Kien and Kemp 1994: 679). Thus of Pöppel's four cited sources, one supports the claim of a temporal window controlling speech for single-intonationcontour utterances, one shows that it is true only for reading verse but not otherwise, and two do not address the issue at all. I conclude that Pöppel has not provided good evidence for a general principle of organizing speech into three-second sections.

\section{The two-second phonological loop of Baddeley and Hitch}

Pöppel does not refer specifically to working memory or short term memory, instead preferring to describe the time-limited auditory capacity as a matter of consciousness. However, the closest we can come to his approach within more standard approaches to psychology are accounts of working (or short term) memory, this being the type of memory which enables us to process sensory inputs, including memory for sound. One of the standard accounts of working memory for the past few decades has been that of Baddeley and Hitch (e.g., as summarized in Baddeley 2012). Theirs is a multi-component model; one of the components is a memory specifically for auditory input. They call this component the 'phonological loop'; it is a time-limited type of memory and thus it has some similarity to TP's 'auditory present'. However, the evidence they have gathered suggests that the phonological loop has a duration of only about two seconds, which is at the bottom end of Pöppel's (2009) more generous 2-3 second window, and well below TP's 3 second auditory present. Thus, they say that the phonological loop is 'a store for speech-coded information that decays in the order of two seconds but can be refreshed by subvocal rehearsal' (Baddeley et al 2009: 439). The key aspect of the phonological loop is that the verbatim sequence of words is remembered by subvocalization ('speaking' it silently to oneself), and that 'people are able to remember as many words as they can articulate in two seconds' (Baddeley 2012: 12).

\footnotetext{
${ }^{7}$ Kien and Kemp (1994) conducted an experiment in which five German speakers read aloud six German poems (a total of 213 lines each), and five Korean speakers five Korean poems (a total of 56 lines each). Kien and Kemp give median line durations for each poem read by each subject, but like average line durations, this is not very informative (other than that it shows inter-individual variation in median line duration for the same poems). More relevant for our purposes is how many lines are longer than three seconds. For the German poems, almost all the lines were three seconds or less (about $2 \%$ of lines longer than this), while for the Korean poems, about $18 \%$ of the lines were longer than three seconds (but almost none longer than four seconds). Kien and Kemp conclude that TP are right to say that lines fall within a clearly definable time window, of between 0.5 and 4 seconds (but they do not explicitly note that 4 seconds is a wider window than TP or indeed Pöppel allow). However, they disagree with TP's universalist claim, noting that German and Korean speakers show a slight but significant difference (Kien and Kemp 1994: 678), and suggesting that other factors may be involved (but note that it is not clear for TP what these would be, because the time window is meant to match the line duration at a basic pre-cultural level). They also disagree with TP's proposal that the time-window is shared by verse and by speech in general. In general, TP does not really receive much support from this article.
} 
Note that we cannot immediately conclude that a line which takes e.g., 3.5 seconds to say could not be fitted into a 2 second phonological loop.

Experiments have shown that the speed at which digits are presented has very little effect on how many digits can be held in the phonological loop, because they can be subvocalized more quickly than they are presented. As regards verse, consider for example the possiblility that as the line is spoken, the words are subvocally repeated by the hearer more rapidly than they are heard spoken; if this happened, it would be possible for the hearer to build up a rapidly subvocalised two-second sequence comprised of the words in the line in the course of hearing a less rapidly overtly vocalized three and a half second spoken line. If this was in fact happening, then there would be an indirectly set psychological limit on the duration of metrical lines in performance: the limit would be how many syllables could be subvocalized in two seconds, and that would be the upper number of syllables in the line. The duration of performed lines would then be irrelevant. However, there is no evidence that accelerated subvocalization is what hearers are doing when they are listening to verse, and it has never been reported: it does not match our phenomenology of listening. As such, I do not pursue this issue further here, and conclude that the much reduced timespan of two seconds in the Baddeley-Hitch model is incompatible with the actual durations of most spoken lines.

The Baddeley-Hitch model of working memory is in another way significantly different from Pöppel's view of time-limited cognition. Pöppel sees cognition as progressing (quantally) in short-duration chunks, while Baddeley and Hitch allow a continuous flow through the phonological loop, not in discrete short-duration chunks. The Pöppel model fits with the idea that the line is also a chunk of a certain duration, which might be processed as a whole. The notion that the line is a whole unit in working memory, such that all the words are held in one place and processed as a single series, is attractive: it fits for example with the fact that metre is a whole-line phenomenon, such that identifying a text as in a particular metre must involve taking the whole line as a single unit (see e.g., Tsur 1998 for arguments). The Baddeley-Hitch model does offer a way of fitting the verse line into working memory, but not in a time-limited part of working memory. This is the episodic buffer, the component which draws on information from the phonological loop and other sources, organizes this information into chunks, and can hold up to about fifteen words of connected speech: a whole line of verse could easily be held in this part of working memory, based not on duration but on other factors such as number of words. I explore this possibility further in Fabb (2014).

\section{Stretches of speech separated by pauses, and the tempo of spoken verse}

In the first part of this paper I have shown that the corpus of recorded poetry does not support the claim that lines take about three seconds to say. In the second part of this paper I ask a question in the spirit of TP but about a different sub-sequence of the text: instead of focusing on lines, we might instead focus on stretches of speech bounded by pauses. When performers read poems 
aloud, they do not necessarily pause at line boundaries; instead the text is divided into different, usually shorter, sections, by pauses (and line boundaries can be lost completely in the spoken performance). Are these stretches of speech the time-limited units of approximately three seconds, which TP seek in performed poetry? (Note that this would work against their larger agenda, which is to show that metrical verse has specific properties, depending specifically on the line; but it is worth asking the question anyway.)

To examine this type of material, I analysed a corpus consisting of 18 of the poems from the first corpus, plus the initial sections of three free-verse poems, along with the spoken introductions to two of the free-verse poems, giving 23 texts in all. For each text, I ignored line boundaries and instead divided the text into fluent articulation sequences with no internal pauses but each preceded and followed by a pause. Shakespeare's sonnet 127, performed by Jonathan Keeble, has articulation sequences as shown in Figure 4.
A B

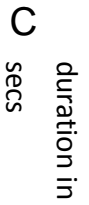

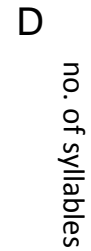
E $\quad F$
忿

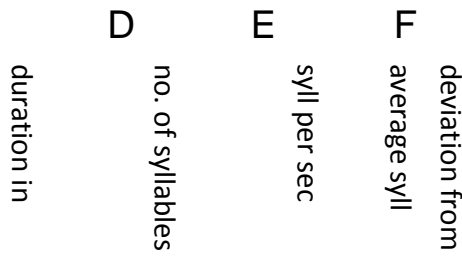
1 In the old age
1.42
4
2.81
$-0.30$
2 [pause]
0.75
3 Black
0.67
1
1.48
$4 \quad$ [pause]
0.43
5 was not counted fair, /
$1.37 \quad 5$
3.65
6 [pause]
0.62
7 Or if it were, it bore not beauty's name; /
2.84
10
3.53
8 Pause
0.60
9 But now
0.68
2
2.94
10 [pause]
0.39
11 is black beauty's successive heir, /
2.38
8
12 [pause]
0.36
13 And beauty slander'd
1.43

5
3.49
0.38
14 [pause]
0.55
15 with a bastard shame: /
1.51
5
3.31
0.21
16 [pause]
0.65 

A B

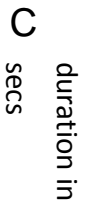

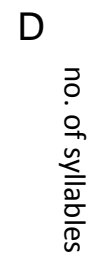
E $\quad F$

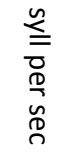

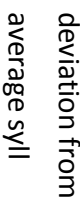
17 For since each hand hath put on nature's 3.05
10
3.28
0.17 power, /
18 [pause]
0.57
19 Fairing the foul with art's false borrow'd
$4.74 \quad 10$
$2.11 \quad-1.00$ face,/
20 [pause]
0.32
21 Sweet beauty hath no name,
2.156
2.80
$-0.31$
22 [pause]
0.30
23 no holy bower, /
$\begin{array}{llll}1.15 & 4 & 3.47 & 0.36\end{array}$
24 [pause]
0.33
25 But is profaned,
$\begin{array}{llll}1.32 & 4 & 3.04 & -0.07\end{array}$
26 [pause]
0.36
27 if not lives in disgrace. /
$2.20 \quad 6$
$2.73 \quad-0.37$
28 [pause]
1.16
29 Therefore
0.67
$30 \quad$ [pause]
0.74
31 my mistress's eyes are raven black, /
$\begin{array}{llll}3.11 & 8 & 2.58 & -0.53\end{array}$
32 [pause]
0.68
33 Her eyes so suited, and they mourners
7.44 seem / At such who, not born fair, no beauty lack, /
34 [pause]
0.66
35 Slandering creation with a false esteem: / 3.03
36 [pause]
0.79
37 Yet so they mourn,
$1.10 \quad 4$
$3.65 \quad 0.54$
38 [pause]
0.60
39 becoming of their woe, /
1.396
$4.32 \quad 1.22$ 
A B

40 [pause]

41 That every tongue

42 [pause]

43 says beauty should look so. /

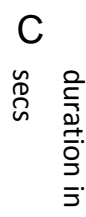

D

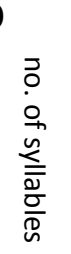

$\mathrm{E}$

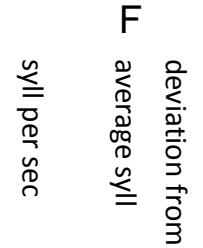

0.79

1.154

3.48

0.37

0.55

1.78

6

3.37

0.26

Figure 4. Shakespeare sonnet 127 performed by Jonathan Keeble: fluent articulation sequences bounded by pauses.

Durations of the 22 fluent articulation sequences which make up the performed poem are given in Figure 4 above, as are the durations of the 21 pauses which separate them. Each fluent articulation sequence has its syllables counted, and then its syllables per second calculated. The average syllable per second rate for all the articulation sequences is calculated (it is 3.11 syllables per second for this poem), and the final column shows whether the syllable per second rate of each section is faster or slower than average (a positive number means faster, a negative number means slower). In this way, tempo changes can be seen.

\begin{tabular}{|c|c|c|c|c|c|c|c|c|c|c|c|}
\hline A & B & $C$ & $D$ & $E$ & $F$ & $\mathrm{G}$ & $\mathrm{H}$ & I & J & K & L \\
\hline $\begin{array}{l}\frac{n}{\bar{a}} \\
\frac{1}{7} \\
\frac{\overrightarrow{ \pm}}{\bar{D}}\end{array}$ & $\begin{array}{l}3 \\
0 \\
0 \\
0 \\
1 \\
0 \\
0 \\
0\end{array}$ & 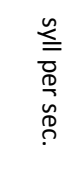 & 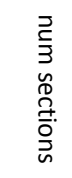 & 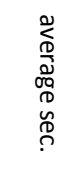 & 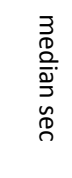 & 蒂 & $\begin{array}{l}\stackrel{\circ}{ } \\
\tilde{D} \\
\stackrel{D}{v} \\
\omega\end{array}$ & 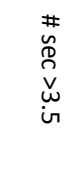 & $\begin{array}{l}\stackrel{\circ}{0} \\
\tilde{D} \\
\stackrel{1}{0} \\
\stackrel{w}{w} \\
\text { in }\end{array}$ & 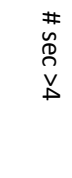 & $\begin{array}{l}\stackrel{\circ}{ } \\
\text { Dे } \\
\hat{D} \\
\dot{D}\end{array}$ \\
\hline $\begin{array}{l}\text { Tree/Juli } \\
\text { us Caes. } \\
3.1\end{array}$ & $\begin{array}{l}\text { iam. } \\
\text { pent. }\end{array}$ & 2.49 & 33 & 2.68 & 2.15 & 11 & 33 & 7 & 21 & 3 & 9 \\
\hline $\begin{array}{l}\text { Bogan } \\
\text { Dream }\end{array}$ & $\begin{array}{l}\text { loose } \\
\text { iam. } \\
\text { pent. }\end{array}$ & 2.74 & 40 & 1.78 & 1.64 & 2 & 5 & 2 & 5 & 1 & 3 \\
\hline $\begin{array}{l}\text { Piazza/S } \\
\text { h son.19 }\end{array}$ & $\begin{array}{l}\text { iam. } \\
\text { pent. }\end{array}$ & 2.97 & 20 & 2.26 & 2.18 & 5 & 25 & 2 & 10 & 1 & 5 \\
\hline $\begin{array}{l}\text { Keeble/S } \\
\text { h } \\
\text { son. } 127\end{array}$ & $\begin{array}{l}\text { iam. } \\
\text { pent. }\end{array}$ & 3.11 & 22 & 2.12 & 1.47 & 5 & 23 & 2 & 9 & 2 & 9 \\
\hline $\begin{array}{l}\text { Carvel/S } \\
\text { h son.6 }\end{array}$ & $\begin{array}{l}\text { iam. } \\
\text { pent. }\end{array}$ & 3.21 & 19 & 2.30 & 1.90 & 5 & 26 & 1 & 5 & 1 & 5 \\
\hline $\begin{array}{l}\text { White/Sh } \\
\text { son.109 }\end{array}$ & $\begin{array}{l}\text { iam. } \\
\text { pent. }\end{array}$ & 3.25 & 23 & 1.83 & 1.66 & 2 & 9 & 1 & 4 & 1 & 4 \\
\hline
\end{tabular}




\begin{tabular}{|c|c|c|c|c|c|c|c|c|c|c|c|}
\hline A & $B$ & $C$ & D & $E$ & $F$ & $\mathrm{G}$ & $\mathrm{H}$ & I & $\mathrm{J}$ & $\mathrm{K}$ & $\mathrm{L}$ \\
\hline $\begin{array}{l}\frac{n}{\bar{O}} \\
\frac{\partial}{7} \\
\stackrel{\vec{F}}{\bar{D}}\end{array}$ & 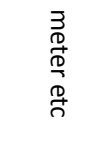 & 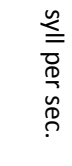 & 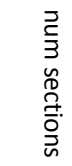 & 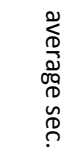 & 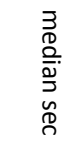 & $\begin{array}{l}\text { 蒂 } \\
\stackrel{D}{D} \\
\text { w }\end{array}$ & 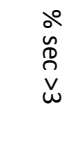 & 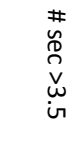 & $\begin{array}{l}\stackrel{\circ}{0} \\
\tilde{D} \\
\stackrel{D}{v} \\
\stackrel{\omega}{u} \\
\text { in }\end{array}$ & 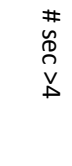 & 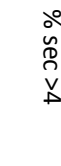 \\
\hline $\begin{array}{l}\text { Soames/ } \\
\text { Sh son } \\
50\end{array}$ & $\begin{array}{l}\text { iam. } \\
\text { pent. }\end{array}$ & 3.28 & 22 & 1.90 & 1.68 & 1 & 5 & 0 & 0 & 0 & 0 \\
\hline $\begin{array}{l}\text { Tennant/ } \\
\text { Sh son } 2\end{array}$ & $\begin{array}{l}\text { iam. } \\
\text { pent. }\end{array}$ & 3.31 & 25 & 1.69 & 1.46 & 2 & 8 & 0 & 0 & 0 & 0 \\
\hline $\begin{array}{l}\text { Ross/Sh } \\
\text { son } 20\end{array}$ & $\begin{array}{l}\text { iam. } \\
\text { pent. }\end{array}$ & 3.34 & 29 & 1.57 & 1.49 & 1 & 3 & 1 & 3 & 0 & 0 \\
\hline $\begin{array}{l}\text { Millay } \\
\text { Recuerd } \\
0\end{array}$ & $\begin{array}{l}\text { loosiii } \\
\text { am tet }\end{array}$ & 3.41 & 38 & 1.72 & 1.67 & 3 & 8 & 1 & 3 & 1 & 3 \\
\hline $\begin{array}{l}\text { Lesser/S } \\
\text { h son } 63\end{array}$ & $\begin{array}{l}\text { iam. } \\
\text { pent. }\end{array}$ & 3.45 & 24 & 1.68 & 1.35 & 4 & 17 & 2 & 8 & 1 & 4 \\
\hline $\begin{array}{l}\text { Cauthery } \\
\text { /Sh son } \\
33\end{array}$ & $\begin{array}{l}\text { iam. } \\
\text { pent. }\end{array}$ & 3.48 & 16 & 2.52 & 2.15 & 4 & 25 & 2 & 13 & 2 & 13 \\
\hline $\begin{array}{l}\text { Timson/ } \\
\text { Sh son } \\
25\end{array}$ & $\begin{array}{l}\text { iam. } \\
\text { pent. }\end{array}$ & 3.50 & 24 & 1.66 & 1.08 & 3 & 13 & 2 & 8 & 2 & 8 \\
\hline $\begin{array}{l}\text { McMillan } \\
\text { /Sh son } \\
91\end{array}$ & $\begin{array}{l}\text { iam. } \\
\text { pent. }\end{array}$ & 3.53 & 19 & 2.12 & 1.99 & 3 & 16 & 1 & 5 & 1 & 5 \\
\hline $\begin{array}{l}\text { Gonet/S } \\
\text { h son } 30\end{array}$ & $\begin{array}{l}\text { iam. } \\
\text { pent. }\end{array}$ & 3.61 & 16 & 2.40 & 2.50 & 4 & 25 & 2 & 13 & 2 & 13 \\
\hline $\begin{array}{l}\text { Frost } \\
\text { Silken } \\
\text { Tent }\end{array}$ & $\begin{array}{l}\text { iam. } \\
\text { pent. }\end{array}$ & 3.67 & 9 & 4.18 & 4.26 & 6 & 67 & 5 & 56 & 5 & 56 \\
\hline $\begin{array}{l}\text { Ginsberg } \\
\text { Kaddish }\end{array}$ & $\begin{array}{l}\text { not } \\
\text { metric } \\
\text { al }\end{array}$ & 3.71 & 43 & 1.71 & 1.56 & 3 & 7 & 2 & 5 & 0 & 0 \\
\hline $\begin{array}{l}\text { Mison/S } \\
\text { h son } \\
133\end{array}$ & $\begin{array}{l}\text { iam. } \\
\text { pent. }\end{array}$ & 3.84 & 22 & 1.67 & 1.38 & 1 & 5 & 0 & 0 & 0 & 0 \\
\hline $\begin{array}{l}\text { Olson } \\
\text { Dogt II }\end{array}$ & $\begin{array}{l}\text { not } \\
\text { metric } \\
\text { al }\end{array}$ & 3.86 & 22 & 1.99 & 1.46 & 6 & 27 & 4 & 18 & 2 & 9 \\
\hline
\end{tabular}




\begin{tabular}{|c|c|c|c|c|c|c|c|c|c|c|c|}
\hline A & B & C & D & $E$ & $F$ & $\mathrm{G}$ & $\mathrm{H}$ & 1 & $\mathrm{~J}$ & $\mathrm{~K}$ & $\mathrm{~L}$ \\
\hline 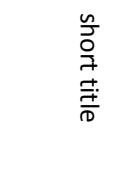 & $\begin{array}{l}3 \\
0 \\
0 \\
0 \\
0 \\
0 \\
0 \\
n\end{array}$ & 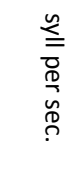 & 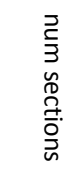 & 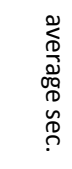 & 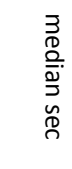 & $\begin{array}{l}\text { 䓌 } \\
\stackrel{d}{0} \\
\stackrel{\omega}{\omega}\end{array}$ & $\begin{array}{l}\stackrel{\circ}{u} \\
\stackrel{0}{0} \\
\stackrel{D}{\omega} \\
\omega\end{array}$ & $\begin{array}{l}\# \\
\stackrel{\#}{D} \\
\stackrel{n}{v} \\
w \\
\text { in }\end{array}$ & 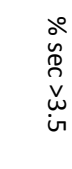 & 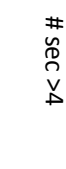 & $\begin{array}{l}\stackrel{\circ}{u} \\
\stackrel{0}{0} \\
\stackrel{D}{\triangleright}\end{array}$ \\
\hline $\begin{array}{l}\text { Ginsberg } \\
\text { speaking }\end{array}$ & $\begin{array}{l}\text { ordina } \\
\text { ry } \\
\text { speec } \\
h\end{array}$ & 4.10 & 11 & 2.20 & 1.40 & 2 & 18 & 2 & 18 & 2 & 18 \\
\hline $\begin{array}{l}\text { Peake/S } \\
\text { h son } 90\end{array}$ & $\begin{array}{l}\text { iam. } \\
\text { pent. }\end{array}$ & 4.10 & 20 & 1.70 & 1.37 & 2 & 10 & 2 & 10 & 1 & 5 \\
\hline $\begin{array}{l}\text { Ferlingh } \\
\text { etti } \\
\text { underwr }\end{array}$ & $\begin{array}{l}\text { not } \\
\text { metric } \\
\text { al }\end{array}$ & 4.17 & 66 & 2.32 & 2.09 & 10 & 15 & 7 & 11 & 5 & 8 \\
\hline $\begin{array}{l}\text { Olson } \\
\text { speaking }\end{array}$ & $\begin{array}{l}\text { ordina } \\
\text { ry } \\
\text { speec } \\
h\end{array}$ & 4.45 & 19 & 1.46 & 1.48 & 0 & 0 & 0 & 0 & 0 & 0 \\
\hline
\end{tabular}

Table 6 Fluent speech between pauses, and articulation rates.

Table 6 starts from these calculations and then displays the data by adding some further calculations. The average syllables per second is given in column $\mathrm{C}$. The average number of syllables per section is shown in column $\mathrm{E}$, and the median number of syllables per section in $F$. Then the number and percentage of fluent articulation sequences which are longer than 3 seconds $(G, H)$, longer than $3.5(\mathrm{I}, \mathrm{J})$ and longer than 4 seconds $(\mathrm{K}, \mathrm{L})$. For our example poem (Keeble/Sh son 127), 23\% of the articulation sequences are longer than 3 seconds, $9 \%$ are longer than 3.5 seconds, and (the same two sequences show up again as) $9 \%$ longer than 4 seconds.

Rather than treating lines as the units which are held as wholes in a time-limited psychological capacity, could we instead treat the stretches of speech between pauses as the sections which are held in this time-limited psychological capacity? The answer is 'no'. Even though these stretches tend to be shorter than lines, many are longer than three seconds (assuming that this is the relevant time-limit as TP claim), and more still are longer than two seconds (assuming the time limit set by Baddeley and Hitch). There is thus no reason to think that these non-line segments of fluent speech are fitted into a time-limited psychological capacity.

I have mixed some free verse and some ordinary (improvised) speech into Table 6, to show that (in this small and unrepresentative corpus) there is no divide between performed metrical verse and other types of verse, when the text is analysed into stretches of speech between pauses. This is relevant because TP say that the time-limited capacity distinguishes between metrical and nonmetrical verse; this is at least not true for stretches of fluent speech. It is 
incidentally worth noting that layout on the page does not necessarily translate into performed sections: Ginsberg's 'Kaddish' is in very long lines on the page, and Olson's 'Maximus, from Dogtown II' is in very short lines on the page but they are performed in similarly short bursts: as the Table shows, they are fairly similar in the average duration of spoken sections.

Table 6 tells us something about the tempo of spoken verse which was not possible for the line-analysis corpus (Table 1). Once we separate the text into fluent articulation sequences, we can determine the articulation rate of the poems, calculated as the rate of syllables per second excluding pauses. (Syllable counts here are estimated, based on the text, ie. 'phonemic syllables'. In other work on speech tempo, this is one of the commonly used measures, e.g., by Trouvain 2003.) The metrical verse texts tend to have slower speech tempos than the non-metrical (free) verse or the spoken sections, and overall the speech tempo for the performance of poetry is relatively slow. The eighteen metrical texts vary in average tempos from 2.49 syllables per second at the slowest to 4.10 syllables per second at the fastest; sixteen of the eighteen metrical texts have average tempos of 3.67 syllables per second or shorter. The relative slowness of these tempos can be seen when these rates are compared with some reported syllable per second articulation rates (excluding pauses) for English. Other published research has reported results that speakers read news at 5.4 syllables per second, read neutral text at 5.49 and 5.43 syllables per second, speak spontaneously at 6.02 and 5.52 syllables per second, and speak spontaneously in radio interviews at 5.17 and 5.29 syllables per second (Trouvain 2003: 7). These are all at a faster tempo than the tempo at which poems are performed in these recordings. ${ }^{8}$

There are probably several reasons for the relatively slow tempo of spoken poetry, including the fact that where the information content of speech is unpredictable, people speak more slowly. Poems have very little redundancy of information - what is said next is likely to be unpredictable - and this will slow down the speakers.

It is worth noting that if people performed iambic pentameter lines at the kind of speech rates reported for general (non-verse) readings, and did not pause midline, it would be possible to produce the ten syllable line within about two seconds. It is also worth noting that even at the tempo at which these poems are spoken, if the lines were spoken without internal pauses, most 10-syllable

\footnotetext{
${ }^{8}$ Byers (1979) conducted an experiment where she recorded six experienced readers reading poetry and prose. Her results show poetry read at an average (over all the readings) of 4.84 syllables per second, a faster average than any of the poets in our sample, and prose read at an average of 6.20 syllables per second. The distinction between slower poetry and faster prose still holds, and Byers has various useful comments to make about why poetry should be read differently (including more slowly). It is worth noting that at Byers's average rate of 4.84 syllable per second it should be possible to perform iambic pentameter lines in three seconds, even with a second-long pause within the line; perhaps fast readers of this kind were responsible for the kinds of result reported by TP. We might question whether the fast tempo of these poetry readings is an artifact of the experimental situation, where readers are not addressing their poems to an audience who must understand them.
} 
lines would indeed be around three seconds long. Thus, there are two routes by which much of this metrical poetry could be performed in ways which would produce approximately three second lines (as required by TP): to speak faster or to speak without pauses. But both would reduce the comprehensibility of these complex texts. TP's supposed upper limit of three seconds on the time of lines is in conflict with the need to make those lines comprehensible when heard.

\section{Conclusion}

Turner and Pöppel offered something rare in literary studies: a counterfactual claim, a claim which is open to being tested and can be shown to be wrong. This is a good thing, and in part explains why their article - despite its faults and oddities - has been cited subsequently. In the present paper, I have taken up the challenge of Turner and Pöppel's counterfactual, and have argued that it is wrong. I have proposed that there is no foundation either for their psychologically-based distinction between traditional (metrical) and modernist (free) verse, and no evidence for a fit between a psychologically-defined temporal window and the durations of metrical lines in performance.

Jakobson (1987: 79) distinguished between verse design and verse instance on the one hand and delivery design and delivery instance on the other. For Shakespeare sonnet 127 performed by Jonathan Keeble, the verse design is shared by all fourteen lines and includes that it is in iambic pentameter; each of the lines is a verse instance, a way in which iambic pentameter is manifested at a textual level as a structured sequence of words with predictable stress patterns. The verse design and instance are characteristics of the text, irrespective of who reads it, unlike the delivery design and instance which characterise a specific reading. The delivery instances are Keeble's actual performances of the lines, with specific phonetic characteristics, and the delivery design is a set of generalizations over the delivery instances (e.g., general characteristic of tempo, patterns of performance which hold over this delivery of the text). Time is a characteristic only of delivery instance, not of verse instance or verse design. TP's proposal is essentially that a temporal constraint on delivery instance can become a non-temporal constraint on verse design, realized in abstract form; for example, a three-second limit on duration of line delivery becomes a constraint on verse design that lines should be ten syllables long, e.g., iambic pentameter. The present paper has shown that this is not correct. This brings us back, however, to one of the reasons TP's proposal may appeal to some of the more empiricist and embodied approaches within cognitive poetics, their claim that it is interaction with the real (temporal) world which structures poetic composition. At least in this case, this claim appears to be untrue.

By removing temporal duration from consideration, we can focus our investigations about limited capacity on the design rather than the delivery of the verse. There are ways of investigating limits on the length of lines, which are not based on time, as Boyd (2012: 41) and Hogan (1997: 242) have suggested. 
There may be cognitively-set limits on the number of syllables, words, or chunks, which are based on linguistic structure (verse design and instance) rather than on the time it takes to deliver them. These would take us in the direction favoured by generative linguistic and other linguistic approaches to poetics, focusing on the verse design rather than the delivery of the poem, on the underlying representations of the language of the text, rather than the embodied experience of the text in performance.

\section{Acknowledgements}

Stefano Versace performed the Praat analysis of line duration in the corpus. Anja Lowit advised on Praat and suggested a script for extracting data from textgrids. Thanks also to Alice Turk for advice. Stefano Versace and Gary Thoms provided useful comments on earlier drafts of this paper, and I thank also the anonymous reviewers for this Journal.

\section{Appendix: Details of poems used}

fswl = From Shakespeare with love (Naxos AudioBooks, 2009).

$\mathrm{dt}=$ Dylan Thomas. A private reading (Tŷ Llên Publications, 2003).

itovA, itovB, itovC $=$ Presson, Rebekah and David McLees. In their own voices. $A$ century of recorded poetry (Rhino Records. R2/R4 72408, 1996.).

$\mathrm{Gi}=$ Allen Ginsberg Howl and other poems (Fantasy 7006, 1998).

hsA = Great historical Shakespeare recordings (Naxos audiobooks, 2000).

$\mathrm{OI}=$ Charles Olson reads from Maximus poems IV, V, VI (Folkways records FL9738, 1975).

psA, psB, psC, psD = Paschen, Elise and Rebekah Presson Moody. Poetry speaks (Sourcebooks inc.: Illinois, 2001).

\section{Poems}

short title / source (as above) / author / full title / read by

Auden If I could / psB / W H Auden / If I Could Tell You / author

Auden In memory / itovA / W.H. Auden / In Memory Of W.B. Yeats (Part 1) / author

Bogan Dream / psB / Louise Bogan / The Dream / author

Bogan Last Act / psB / Louise Bogan / Song For The Last Act / author

Bourchier/Macbeth 2.1 / hsA / William Shakespeare / Macbeth: Act 2: Scenes 1 \& 2 'Go Bid Thy Mistress' / Arthur Bourchier

Carvel/Sh son.6 / fswl / William Shakespeare / Sonnet 6: Then Let Not Winter's Ragged Hand Deface / Bertie Carvel

Cauthery/Sh son 33 / fswl / William Shakespeare / Sonnet 33: Full Many A Glorious Morning Have I Seen / Gunnar Cauthery 
cummings anyone / itovA / E.E. Cummings / Anyone Lived In A Pretty How Town / author

cummings next to / itovA / E.E. Cummings / Next To Of Course God America / author

Ferlinghetti see it was / itovB / Lawrence Ferlinghetti / See It Was Like This When... / author

Ferlinghetti underwr / itovB / Lawrence Ferlinghetti / Underwear / author

Frost Birches / itovA / Robert Frost / Birches / author

Frost Gift Outright / itovA / Robert Frost / The Gift Outright / author

Frost Nothing gold / psA / Robert Frost / Nothing Gold Can Stay / author

Frost Oven Bird / psA / Robert Frost / The Oven Bird / author

Frost Road not taken / itovA / Robert Frost / The Road Not Taken / author

Frost Silken Tent / psA / Robert Frost / The Silken Tent / author

Frost Stopping / psA / Robert Frost / Stopping By Woods On A Snowy Evening / author

Gielgud Richard II 3.3 / hsA / William Shakespeare / Richard 2: Act 3: Sc. 3 ‘O God! O God!...' / John Gielgud

Gielgud/Hamlet 4.4 / hsA / William Shakespeare / Hamlet: Act 4: Sc. 4 'How All Occassions Do Inform Against Me...' / John Gielgud

Ginsberg Kaddish / Gi / Allen Ginsberg / Kaddish (Part 1), first ten lines of poem / author

Ginsberg speaking / Gi / Allen Ginsberg / Kaddish (Part 1), spoken (prose) introduction to poem, not followed by poem / author

Gonet/Sh son 30 / fswl / William Shakespeare / Sonnet 30: When The Sessions Of Sweet Silent Thought / Stella Gonet

Graves To Juan / itovA / Robert Graves / To Juan At The Winter Solstice / author

Irving/Richard III 1.1 / hsA / William Shakespeare / Richard 3: Act 1: Sc. 1 'Now Is The Winter Of Our Discontent...' / Henry Irving

Keeble/Sh son.127 / fswl / William Shakespeare / Sonnet 127: In The Old Age Black Was Not Counted Fair / Jonathan Keeble

Lesser/Sh son 63 / fswl / William Shakespeare / Sonnet 63: Against My Love Shall Be As I Am Now / Anton Lesser

McMillan/Sh son 91 / fswl / William Shakespeare / Sonnet 91: Some Glory In Their Birth, Some In Their Skill / Roy McMillan

Millay I shall forget / psB / Edna St. Vincent Millay / I Shall Forget You Presently, My Dear / author

Millay Love is not / itovA / Edna St. Vincent Millay / Love Is Not All / author

Millay Recuerdo / itovA / Edna St. Vincent Millay / Recuerdo / author

Mison/Sh son 133 / fswl / William Shakespeare / Sonnet 133: Beshrew That Heart That Makes My Heart To Groan / Tom Mison

Olson Dogt II / OI / Charles Olson / Maximus, from Dogtown II, first 39 lines / author /

Olson Dogt II plus / Ol / Charles Olson / Maximus, from Dogtown II (prose) introduction to poem followed by the first 39 lines (with Intro.) / author 
Olson speaking / Ol / Charles Olson / Maximus (prose) introduction to poem only, not followed by poem / author

Parker Afternoon / psB / Dorothy Parker / Afternoon / author

Parker One perfect / psB / Dorothy Parker / One Perfect Rose / author

Parker Resumé / psB / Dorothy Parker / Resumé / author

Peake/Sh son 90 / fswl / William Shakespeare / Sonnet 90: Then Hate Me When Thou Wilt; If Ever, Now / Maxine Peake

Piazza/Sh son.19 / fswl / William Shakespeare / Sonnet 19: Devouring Time, Blunt Thou The Lion's Paws / Anne-Marie Piazza

Plath Ariel / itovC / Sylvia Plath / Ariel / author

Plath Daddy / itovC / Sylvia Plath / Daddy / author

Plath Lady Lazarus / psC / Sylvia Plath / Lady Lazarus / author

Pound Hugh Selwyn / itovA / Ezra Pound / Hugh Selwyn Mauberley (Excerpt) / author

Ransom Bells / psA / John Crowe Ransom / Bells For John Whiteside's Daughter / author

Ransom Captain / psA / John Crowe Ransom / Captain Carpenter / author

Robertson Hamlet 2.2 / hsA / William Shakespeare / Hamlet: Act 2: Sc. 2 'O What A Rogue \& Peasant Slave Am 1...' / Johnston Forbes Robertson

Robertson/Hamlet 3.2 / hsA / William Shakespeare / Hamlet: Act 3: Sc. 2 'Speak The Speech I Pray You .....' / Johnston Forbes Robertson

Roethke I knew / itovB / Theodore Roethke / I Knew A Woman / author

Ross/Sh son 20 / fswl / William Shakespeare / Sonnet 20: A Woman's Face With Nature's Own Hand Painted / Hugh Ross

Soames/Sh son 50 / fswl / William Shakespeare / Sonnet 50: How Heavy Do I Journey On The Way / Benjamin Soames

Spender Rough / itovB / Stephen Spender / Rough / author

Tennant/Sh son 2 / fswl / William Shakespeare / Sonnet 2: When Forty Winters Shall Besiege Thy Brow / David Tennant

Tennyson Bugle song / psA / Alfred Tennyson / from The Bugle Song / author

Thomas/Donne hymn / dt / John Donne / Hymn to God, my God in my Sicknes / Dylan Thomas

Thomas/Dover Beach / dt / Matthew Arnold / Dover Beach / Dylan Thomas

Timson/Sh son 25 / fswl / William Shakespeare / Sonnet 25: Let Those Who Are In Favour With Their Stars / David Timson

Tolson Ex-Judge / psB / Melvin B. Tolson / An Ex-Judge At The Bar / author

Tree/Julius Caesar. 3.1 / hsA / William Shakespeare / Julius Caesar: Act 3: Sc. 1 'O Pardon Me Thou Bleeding.. / Herbert Beerbohm Tree

Waller/Henry V 2.1 / hsA / William Shakespeare / Henry V: Act 2: Sc. 1 'Once More Unto The Breach...' / Lewis Waller 
White/Sh son.109 / fswl / William Shakespeare / Sonnet 109: O! NeverSay That I Was False Of Heart / Trevor White

Yeats Coole Park / psA / W B Yeats / Coole Park And Ballylee, 1931 / author

Yeats Lake Isle / itovA / William Butler Yeats / The Lake Isle Of Innisfree / author

Yeats Old Mother / itovA / William Butler Yeats / The Song Of The Old Mother / author

\section{References}

Baddeley, Alan (2012). Working Memory: Theories, Models, and Controversies. Annual Review of Psychology. 63, 1-29.

Baddeley, A.D., Hitch, G.J., \& Allen, R.J. (2009). Working Memory and Binding in Sentence Recall. Journal of Memory and Language, 61, 438-456.

Blacking, John (1995). Venda Children's Songs. A Study in Ethnomusicological Analysis. Chicago: University of Chicago Press.

Boyd, Brian (2012). Why Lyrics Last. Evolution, Cognition and Shakespeare's Sonnets. Cambridge MA: Harvard UP.

Byers, Prudence P. (1979). A Formula for Poetic Intonation. Poetics 8(4), 367-380.

Evans, Vyvyan (2007). How we Conceptualise Time: Language, Meaning and Temporal Cognition. In The Cognitive Linguistics Reader. Edited by Vyvyan Evans, Benjamin K. Bergen and Jörg Zinken. Equinox publishers. 733-765.

Fabb, Nigel (2010). Is Literary Language a Development of Ordinary Language? Lingua. 120/5, 1219-1232.

Fabb, Nigel (2014). The Verse-Line as a Whole Unit in Working Memory, Ease of Processing, and the Aesthetic Effects of form. Philosophy Supplement Vol. 74.

Fabb, Nigel \& Halle, Morris (2008). Meter in Poetry: a New Theory. Cambridge: Cambridge University Press.

Greene, R. (ed) (2012). The Princeton Encyclopedia of Poetry and Poetics. $4^{\text {th }}$ edition. Princeton: Princeton University Press.

Holder, Allan (1995). Rethinking Meter: a New Approach to the Verse Line. Cranbury NJ: Associated University Presses.

Hogan, Patrick Colm (1997). Literary Universals. Poetics Today, 18(2): 223-249.

Jakobson, Roman (1987). Closing Statement: Linguistics and Poetics. In K. Pomorska \& S. Rudy (eds), Roman Jakobson. Language in Literature. Cambridge MA: Harvard University Press. 62-94.

Kien, J. \& Kemp, A. (1994). Is Speech Temporally Segmented? Comparison with Temporal Segmentation in Behavior. Brain and Language 46, 662-682.

Kowal, S., O'Connell, D. C. \& Sabin, E. J. (1975). Development of Temporal Patterning and Vocal Hesitations in Spontaneous Narratives. Journal of Psycholinguistic Research 4, 195-207.

Martin, J. G. (1972). Rhythmic (Hierarchical) Versus Serial Structure in Speech and other Behavior. Psychological Review 79, 487-509. 
Nelson, Helena (2000). New Formalism: A U.K. View. The Dark Horse. Summer 2000. 133-137.

Pöppel, Ernst (2009). Pre-Semantically Defined Temporal Windows for Cognitive Processing Philiosophical Transactions of the Royal Society B. 364, 1887-1896

Trouvain, Jürgen (2003). Tempo Variation in Speech Production. Implications for Speech Synthesis. PhD thesis. Saarbrücken: Universität des Saarlandes

Tsur, Reuven (1998). Poetic Rhythm: Structure And Performance. An Empirical Study In Cognitive Poetics. Berne: Peter Lang.

Turner, Frederick (1992). Natural Classicism. Charlottesville: University Press of Virginia.

Turner, Frederick \& Pöppel, Ernst (1983). The Neural Lyre: Poetic Meter, the Brain, and Time. Poetry 142(5), 277-307.

Turner, Frederick \& Pöppel, Ernst (1988). Metered Poetry, the Brain, and Time. In Beauty and the Brain. Biological Aspects of Aesthetics. ed. Ingo Rentschler, Barbara Herzberger \& David Epstein. Basel: Birkhäuser Verlag. 71-90.

Vierordt, K. (1868). Der Zeitsinn nach Versuchen. Tübingen, Germany: Laupp.

Vollrath, M., Kazenwadel, J. \& Krüger, H.-P. (1992). A Universal Constant in Temporal Segmentation of Human Speech. Naturwissenschaften 79, 479-480. 